\title{
PREDGOVOR
}

\section{IZZIVI NA PODROČJU PRIDOBIVANJA IN ZADRŽEVANJA KADRA: ALI OBSTAJA REŠITEV?}

Pridobivanje in zadrževanje visoko usposobljenega vojaškega kadra sta bistvena za vse oborožene sile. To še toliko bolj velja za Evropo, saj je večina oboroženih sil z naborniškega sistema prešla na prostovoljno služenje vojaškega roka. Na podlagi predstavitev in razprav na 14. konferenci Evropske raziskovalne skupine o vojski in družbi (ERGOMAS - European Research Group on Military and Society), ki je potekala med 26. in 30. junijem 2017 v Atenah v Grčiji, je tokratna tematska številka Sodobnih vojaških izzivov posvečena pridobivanju in zadrževanju zainteresiranih mladih ljudi v oboroženih silah.

V okviru delovne skupine ERGOMAS Pridobivanje in zadrževanje kadra, so strokovnjaki z različnih področij predstavili 20 prispevkov. Na petih konferenčnih sekcijah o tej temi so se razvile zanimive razprave o različnih s tem povezanih tematikah. Na prvi sekciji smo se ukvarjali s temo manjšin v oboroženih silah, in sicer, kako se lahko vključijo in prilagodijo ter kako lahko sodelujejo v sistemu. Predstavitve na drugi sekciji so se osredotočale na pridobivanje in zadrževanje kadra $v$ rezervni sestavi oboroženih sil. Politika in vojska: medsebojni vpliv in učinek na vojaško osebje je bila tema tretje sekcije, na naslednji pa smo analizirali motivacijske dejavnike in razloge za odhode iz vojske. Na zadnji sekciji smo obravnavali strategije za pridobivanje in zadrževanje kadra. S teh petih sekcij smo izbrali pet predstavitev o vsaki tematiki in jih prilagodili za objavo v publikaciji. V petih člankih, ki so na voljo v tej številki, je tema pridobivanja in zadrževanja kadra obširno obravnavana $\mathrm{z}$ zgodovinske perspektive in tudi na podlagi najnovejših izsledkov raziskav.

Na področju vojaške sociologije so se raziskave večinoma nanašale na zaposlovanje prostovoljcev v stalno sestavo, podrobno pa bi bilo treba proučiti tudi rezervne sestave in naborniški sistem. V tej tematski številki se avtorji ukvarjajo tudi z analizo rezervnih sestav in naborniškega sistema z vidika pridobivanja in zadrževanja kadra. 
V Evropi se je tematiki pridobivanja in zadrževanja kadra v preteklosti namenjalo le malo pozornosti. To je v času hladne vojne veljalo tudi za oborožene sile, ki so temeljile na naborništvu - nove vojake je namreč zagotavljal naborniški sistem. Ena izmed prednosti tega sistema je bila, da so se imeli naborniki (v Evropi je bilo služenje vojaškega roka obvezno le za moške, ženske so se oboroženim silam lahko pridružile prostovoljno, v nekaterih državah pa jim je bilo to celo prepovedano oziroma so jim bila namenjena le pomožna delovna mesta) med služenjem vojaškega roka priložnost socializirati in se prepričati, da je vojaški poklic pravi zanje. $Z$ drugimi besedami $-\mathrm{Z}$ naborniškim sistemom so oborožene sile pridobile nove ljudi, ki so bili pripravljeni na dolgotrajno zaposlitev.

Posledično oboroženim silam ni bilo treba iskati novega osebja na trgu delovne sile. »Notranji« sistem pridobivanja kadra z naborništvom je večinoma zadostoval, da so pridobili dovolj pripadnikov in, kar je zelo pomembno, visoko usposobljen kader. S koncem hladne vojne in novimi misijami pa so oborožene sile dobile nove naloge. Za te nove naloge je bil potreben kader, ki je zmogel in bil pripravljen ostati v tujini dlje časa, po drugi strani pa so bile potrebne nove veščine za spoprijemanje z novimi okoliščinami na misijah v tujini. Zaradi konfliktov v 90. letih 20. stoletja, kot so zalivska vojna, državljanska vojna v Somaliji, kjer sta delovali dve misiji ZN (UNOSOM I in II), vojna v Bosni in Hercegovini ter vojna na Kosovu, v katero se je vključil Nato, so imele zahodnoevropske oborožene sile velike težave s pošiljanjem usposobljenega kadra na ta krizna območja. Svojevrsten paradoks je, da je bilo v evropske oborožene sile takrat vključenih precej več vojakov kakor danes, vendar pa je bilo v skoraj vsaki državi prepovedano pošiljati nabornike na misije v tujino. Po koncu hladne vojne torej te oborožene sile niso bile kos novim nalogam.

Z izkušnjami, pridobljenimi na teh misijah, sta se začela procesa združevanja evropskih oboroženih sil $\mathrm{v}$ večnacionalne sestave in njihova profesionalizacija. Zaradi združevanja v večnacionalne sestave je bilo za številne države pomembnejše, da se pridružijo zavezništvom, predvsem Natu. V večnacionalnem okviru se je začel upoštevati vidik večje interoperabilnosti med različnimi oboroženimi silami, kar je vodilo do bolj profesionalnih struktur. Strukturne spremembe se močno kažejo v številu oboroženih sil, ki so opustile naborništvo. Leta 1990 so imele le štiri izmed 26 evropskih držav sistem, ki je temeljil na prostovoljnem popolnjevanju in ne na naborništvu. Danes je večina evropskih držav prešla na prostovoljno popolnjevanje, s tem položajem pa se je spremenil sistem popolnjevanja. Pritok novih nabornikov je usahnil, zato je bilo treba kader iskati na trgu delovne sile.

Hkrati s spreminjanjem podobe oboroženih sil z množične naborniške vojske na manjšo prostovoljno, so se $\mathrm{v}$ civilni družbi začele spreminjati vrednote. Tradicionalne vrednote, kot so poslušnost, disciplina in pokornost, so mladim postajale manj pomembne, bolj cenjene pa so postale druge, kot sta samostojnost in samopotrjevanje. Nekateri izmed vzrokov za te spremembe so bili urbanizacija, vedno višja stopnja izobrazbe ter večje razločevanje in specializacija delovnega okolja. To je povzročilo razhajanje med civilnimi vrednotami, ki v ospredje 
postavljajo posameznika, in vojaškimi vrednotami, ki se osredotočajo na skupino. Trenutno se posledice tega procesa kažejo v težavah pri pridobivanju zadostnega števila kakovostnega vojaškega kadra. Vprašanja o človeških virih so za oborožene sile postala preživetvenega pomena - poleg zapolnitve delovnih mest je potrebno tudi njihovo prilagajanje na nove misije v večkulturnem okolju, kar zahteva nujne ukrepe na področju razvoja človeških virov. Pozornost je zdaj usmerjena v širitev bazena, iz katerega bi bilo mogoče črpati ustrezen kader. V oboroženih silah so se tradicionalno zaposlovali mladi belci, kar bi bilo treba dopolniti z zaposlovanjem žensk in mladih priseljenskega izvora. Drugače povedano: novi ciljni pripadniki oboroženih sil morajo biti v enakovrednem položaju s starejšimi pripadniki, ki tradicionalno prihajajo iz naborniškega sistema. Ob upoštevanju tega morajo evropske oborožene sile preoblikovati svoje nazore o pridobivanju kadra tako, da bodo privlačne za te nove ciljne skupine. Prispevki in raziskave, predstavljeni v tej številki, lahko pripomorejo k širšemu razumevanju novega procesa pridobivanja in zadrževanja kadra.

Želim vam prijetno branje. 